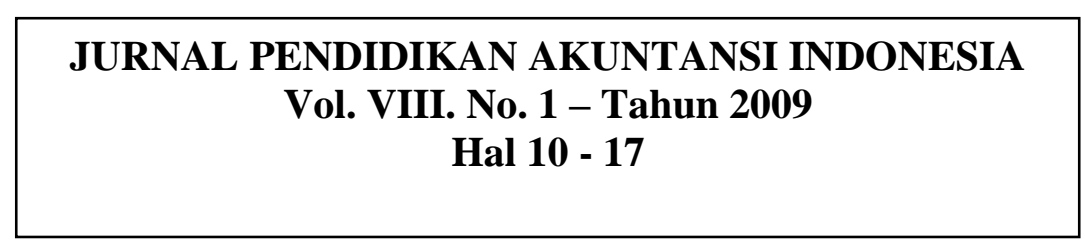

\title{
PENERAPAN MODEL EVALUASI STAKE (COUNTENANCE) UNTUK MENGEVALUASI PEMBELAJARAN DASAR - DASAR AKUNTANSI
}

\author{
Oleh \\ Siswanto ${ }^{1}$
}

\begin{abstract}
This study was aimed at evaluating the Instructional process of Introduction to Accounting subject in Accounting Education Department, Social Science and Economic Faculty, State University of Yogyakarta, including (1) the students' educational background that supports the teaching; (2) the students' learning motivation; (3) the availability and completeness of supporting facilities and infrastructure; (4) the use of facilities and infrastructure to support the teaching process (5) the teaching process; (6) students' understanding after the teaching process, and (7) the students' learning achievement.

This study was an evaluation study using qualitative descriptive data with the Stake model evaluation. The data were collected through a questionnaire, observation, documentation, and interview, and analyzed using the descriptive statistic. The table of frequency distribution and histogram were also presented. The trend for each variable was computed to know the trend categories based on the categories set.

The results of the study show that (1) the educational background of the students taking Introduction to Accounting subject consists of vocational school majoring in accounting (4.44\%), senior high school majoring in exact science (80\%) and senior high school majoring in social science (15.55\%). (2) The students' motivation is categorized as medium,(33.33\% of the questioner and observation data). (3) The infrastructure is quite sufficient,indicated by various media including manual laboratory and computer laboratory. (4) The use of infrastructure is in afairly good category (44.44\%). However, the results of observations show that the use of infrastructure for the teaching process is not optimal yet. (5) The teaching process is in a good category (37.77\%). (6) The students' understanding after having the subject is in a good category $(51,11 \%)$. (7) The students' score, consisting of mid test, final test and student assignments, can be categorized as very good (44.44\%).

Keywords : Evaluation,Instructional, stake Model
\end{abstract}

\section{Pendahuluan}

Keberhasilan LPTK dalam hal ini adalah perguruan tinggi sangat menentukan mutu dari SMK untuk menghasilkan lulusan yang siap pakai. Banyaknya lululan LPTK tidak menjamin baiknya kualitas yang dihasilkan, oleh karena itu sangat perlu dilakukan

${ }^{1}$ Staf Pengajar Jurusan Pendidikan Akuntansi - Universitas Negeri Yogyakarta 
kajian yang mendalam untuk dapat meningkatkan kuantitas serta kualitas LPTK untuk melayani kebutuhan tenaga pendidik ditingkat SMK.

Kompetensi seorang sarjana LPTK dapat tercermin dari jabaran Kurikulum yang telah disusun oleh LPTK untuk kegiatan pembelajaran, proses pelaksanaan pembelajaran serta sarana dan prasarana yang mendukung proses pembelajaran. Keselaraasan antara kurikulum yng telah disusun dengan kebutuhan kompetensi pendidik di tingkat SMK memegang peranan penting, oleh karena itu perlu adanya link and Match antara LPTK dengan para Stake holdernya dalam hal ini adalah SMK.

Program Studi Pendidikan Akuntansi Fakultas Ilmu Sosial Universitas Negeri Yogyakarta merupakan salah satu LPTK penyedia tenaga keguruan yang mengkhususkan pada bidang Akuntansi yang akan di manfaatkan untuk menyediakan tenaga pendidik ditingkat SMK. Secara tidak langsung Program Studi Pendidikan Akuntansi Fakultas Ilmu Sosial dan Ekonomi Universitas Negeri Yogyakarta memiliki andil yang besar dalam rangkan menyediakan tenaga kerja tingkat menengah yang handal dengan penyediaan tenaga pendidik yang profesional. Kesesuaian permintaan kompetensi Dunia Kerja Dunia Industri (DUDI) dengan kompetensi yang diberikan dalam pembelajaran di SMK sangat mempengaruhi keberhasilan penyediaan tenaga kerja ini.

Keberhasilan penyediaan Tenaga pendidik di SMK oleh Program Studi Pendidikan Akuntansi Fakultas Ilmu Sosial dan Ekonomi Universitas Negeri Yogyakarta juga tidak lepas dari adanya tindak lanjut keselarasan yang telah dirintis di tingkat SMK dan DUDI, dengan telah adanya keselarasan tersebut maka Program Studi Pendidikan Akuntansi Fakultas Ilmu Sosial dan Ekonomi Universitas Negeri Yogyakarta telah memiliki bahan referensi dalam melakukan pembelajaran pada peserta didiknya untuk dapat memenuhi kompetensi yang dinginkan oleh SMK yang berawal dari keinginan DUDI. Dengan melihat kondisi tersebut maka sangatlah perlu adanya evaluasi terhadap pembelajaran pada Program Studi Pendidikan Akuntansi Fakultas Ilmu Sosial dan Ekonomi Universitas Negeri Yogyakarta sehingga diperoleh lulusan LPTK yang mempuyai keahlian yang siap untuk mendidik siswa di tingkat SMK sesuai dengan keingian DUDI.

Dalam kegiatan pembelajaran, evaluasi sangat diperlukan untuk kepentingan perbaikan proses pembelajaran yang dilakukan dan bertujuan untuk mengetahui kemajuan peserta didik dalam belajar sesuai dengan tujuan pembelajaran yang telah ditetapkan. Pendekatan evaluasi dalam upaya untuk mengetahui efektivitas pembelajaran Akuntansi Program Studi Pendidikan Akuntansi Fakultas Ilmu Sosial dan Ekonomi Universitas Negeri Yogyakarta akan menggunakan pendekatan evaluasi yang dapat mencakup keseluruhan proses pendidikan, yang menggunakan pendekatan sistem. Dari uraian di atas maka dirumuskan permasalah terkait evaluasi pembelajaran Dasar - dasar sebagai berikut :

Bagaimanakah Karakteristik dan Motivasi Mahasiswa, Ketersediaan sarana dan prasarana dalam program pembelajaran yang mendukung pelaksanaan pembelajaran Dasar - dasar Akuntansi?. Bagaimanakah pelaksanaan proses pembelajaran Dasar dasar Akuntansi?. Bagaimana output kegiatan pembelajaran Dasar - dasar Akuntansi Program Studi Pendidikan Akuntansi Fakultas Ilmu Sosial dan Ekonomi Universitas Negeri Yogyakarta?

\section{Cara Penelitian}

a. Desain dan Subjek Penelitian

Penelitian ini merupakan penelitian Evaluasi ini dilakukan terhadap pembelajaran Mata Kuliah Dasar-dasar Akuntansi pada Program Studi pendidikan Akuntansi Fakultas Ilmu Sosial dan Ekonomi Universitas Negeri Yogyakarta dengan menggunakan 
pendekatan Stake (countenance) yang menfokuskan pada evaluasi yang terkait dengan Antecendent, transaction dan Outcomes

Subjek dalam pelaksanaan evaluasi ini adalah seluruh mahasiswa Program Studi Pendidikan Akuntansi Fakultas Ilmu Sosial dan Ekonomi Universitas Negeri Yogyakarta yang menempuh mata kuliah Dasar-dasar Akuntansi pada Semester Gasal tahun ajaran 2005/2006

b. Metode Pengumpulan Data dan Analisis data

Berbagai metode yang digukanan oleh peneliti dalam pelaksanaan evaluasi ini adalah : Metode Questioner, Wawancara, Dokumentasi, Observasi. Teknik analisis data yang dipergunakan dalam penelitian adalah analisis deskriptif kuantitatif, yaitu mendiskripsikan untuk setiap variabel yang terlibat dalam penelitian ini dengan didukung dengan data kuantitatif. Statistik yang dipergunakan adalah Mean (M), Median (Me), Modus (Mo) dan standart deviasi. Analiasi diskriptif kuantitatif melakukan penilaian berdasar kriteria penilaian yang telah ditentukan berdasarkan hasil penskoran yang telah ditetapkan untuk masing-masing komponen atau sub komponen. Hasil penskoran tersebut selajutnya dibandingkan dengan kriteria penilaiannya. Untuk komponen kriteria penilaian ditetapkan berdasarkan kategori tingkat kebaikannya yaitu kategori baik,cukup,kurang. Penskoran tersebut dengan ,mempertimbangkan Mean (M) dan Simpangan Baku/Stadart Deviasi (SD). Untuk Kategari Masing-masing Kriteria :

$$
\begin{aligned}
& M+1,5 \text { SD Keatas } \\
& M \text { Sampai } M+1,5 \text { SD } \\
& M-1,5 \text { SD sampai } M \\
& M-1,5 \text { SD kebawah }
\end{aligned}
$$$$
\text { : Sangat Tinggi/ Sangat Baik }
$$$$
\text { : Tinggi/Baik }
$$$$
\text { : Sedang/Cukup }
$$$$
\text { : Rendah /Kurang }
$$

\section{Hasil Penelitian dan Pembahasan}

\section{Hasil Evaluasi Antecendent}

\section{a. Pengunaan Sarana Dan Prasarana dalam Pembelajaran}

Dari perhitungan Statistik diperoleh skor rata - rata (Mean) sebesar 22,33, standart deviasi (SD) sebesar 4,21, median sebesar 22,00 dan modus sebesar 22,00 ( hasil perhitungan dapat dilihat pada lampiran). Berdasarkan skor rata - rata ideal (Mean) harapan dan standart deviasi (SD) harapan yang didapat dari perhitungan rumusan keceredungan, maka dapat ditentukan distribusii kecemderungan sebagai berikut :

Tabel. 1

\section{Distribusi Kecenderungan penggunaan Sarana dan Prasarana}

\begin{tabular}{|c|c|c|c|}
\hline Interval Kelas & Frekuensi & $\mathbf{\%}$ & Kategori \\
\hline $27,25-30,00$ & 7 & 15,55 & Sangat Tinggi/Sangat Baik \\
\hline $23,50-27,35$ & 7 & 15,55 & Tinggi/Baik \\
\hline $19,75-23,50$ & 20 & 44,44 & Sedang/Cukup Baik \\
\hline$<19,75$ & 11 & 24,44 & Rendah/Tidak Baik \\
\hline
\end{tabular}

Dari distribusi kecenderungan penggunaan sarana dan prasarana ternyata dari 45 reponden terdapat 7 responden atau 15,55 \% mendapat Skor Sangat tinggi dan Tinggi, 20 responden atau 44,44\% mendapat skor Sedang dan 11 responden atau 24,44 mendapat skor rendah. Berdasarkan data yang diperoleh dapat ditarik kesimpulan bahwa penggunaan sarana dan prasarana dalam pembelajaran pada Program Studi Pendidikan Akuntansi adalah Cukup Baik.

Dari sisi pengunaan sarana dan prasaran pembelajaran juga dapat diperoleh data dari observasi yang dilakukan oleh peneliti. Dari hasil observasi dapat terlihat penggunaan media yang digunakan oleh Dosen pengampu Dasar - Dasar akuntansi 
yang kurang bervariasi, ini terlihat dari berbagai saranan yang disediakan hanya satu yang dominan digunakan oleh dosen yaitu papan tulis. Sebenarnya telah tersedia OHP dan LCD yang dapat digunakan. Dengan kurang bervariasinya media yang digunakan maka mahasiswapun akan cepat merasa jenuh dan bosan. Selain itu dapat terlihat kondisi ruang yang terlalu panjang bentuknya sehingga mahasiswa yang berada di deretan meja tengah kebelakang kurang jelas untuk melihat papan tulis juga mempengaruhi keberhasilan proses pembelajaran. Dari hasil obsevasi dapat disimpulkan bahwa penggunaan sarana dan prasarana oleh dosen pada saat pembelajaran Dasar - Dasar akuntansi dalam kategori Cukup atau belum optimal.

\section{b. Motivasi Belajar Dasar - Dasar Akuntansi Mahasiswa}

Dari hasil penelitian diperoleh skor tertinggi 40 dan skor terendah sebesar 30 . Dari perhitungan Statistik diperoleh skor rata - rata (Mean) sebesar 34,97, standart deviasi (SD) sebesar 2,50, median sebesar 35,00 dan modus sebesar 35,00 ( hasil perhitungan dapat dilihat pada lampiran)

Berdasarkan skor rata - rata ideal (Mean) harapan dan standart Deviasi (SD)harapan yang didapat dari perhitungan rumusan kecenderungan, maka dapat ditentukan distribusdi kecenderungan sebagai berikut :

Tabel. 2

Distribusi Kecenderungan Motivasi Belajar Mahasiswa

\begin{tabular}{|c|c|c|c|}
\hline Interval Kelas & Frekuensi & \% & Kategori \\
\hline $37,50-40,00$ & 8 & 17,77 & Sangat Tinggi \\
\hline $35,00-37,50$ & 13 & 28,88 & Tinggi \\
\hline $32,50-35,00$ & 15 & 33,33 & Sedang \\
\hline$<32,50$ & 9 & 20,00 & Rendah \\
\hline
\end{tabular}

Dari distribusi kecenderungan motivasi belajar mahasiswa dari 45 reponden terdapat 8 responden atau 17,77 \% mendapat Skor Sangat tinggi, 13 responden atau 28,88 \% mendapat skor tinggii, 15 responden atau 33,33 \% mendapat skor Sedang dan 9 responden atau 20,00 \% mendapat skor rendah. Berdasarkan data yang diperoleh dapat ditarik kesimpulan bahwa Motivasi belajar mahasiswa Dasar - dasar akuntansi pada Program Studi pendidikan Akuntansi adalah Sedang.

Dari Hasil observasi saat berlangsung proses pembelajaran peneliti juga dapat melihat motivasi belajar mahasiswa. Pada saat pembelajaran akuntansi tergolong tinggi hal ini terlihat dari respon yang diberikan oleh mahasiswa saat pembelajaran, sering mahasiswa mengajukan berbagai bertanyaan yang terkait dengan materi yang disampaikan oleh dosen pengampu. Selain itu dapat dicermati pula tingkat kehadiran mahasiswa saat pekulihaan yang rata - rata kehadiran mahasiswa adalah $98 \%$. Selain partisi pasi dan kehadiran dalam kuliah motivasi mahasiswa juga dapat terlihat saat diminta oleh dosen untuk mengerjakan soal/kasus yang diberikan mereka dengan tekun dan serius mengerjakan kasus yang diberikan, walau nampak beberapa mahasiswa yang lalu lalang untuk ke meja teman untuk meminta penjelasan dari teman, hal ini memang disarankan oleh dosen untuk membantu ketercapaian tujuan pembelajaran diharapkan mahasiswa yang telah memiliki pemahaman untuk memberi pemahaman pada teman yang lain. Ternyata dengan metode ini mahasiswa akan lebih merasa termotivasui untuk saling membantu dan belajar bersama untuk belajar Dasar - Dasar Akuntansi. Dari hasil observasi dapat disimpulkan bahwa motivasi belajar mahasiswa termasuk dalam kateri yang sedang/baik. 


\section{d. Latar Belakang Pendidikan Mahasiswa}

Latar belakang pendidikan akan membawa peranan yang sangat penting untuk dapat terlaksanakannya Proses pembelajaran Dasar - Dasar Akuntansi, hal ini karena mahasiswa telah memiliki bekal yang cukup untuk menerima materi yang diberikan dalam pembelajaran. Untuk dapat mengikuti Pembelajaran dengan baik adalah Mahasiswa yang memiliki latar belakang pendidikan SMK jurusan Akuntansi, atau SMU jurusan IPS. Mahasiswa yang memiliki latar belakang SMK jurusan Akuntansi akan memiliki bekal yang Paling baik untuk dapat mengikuti Pembelajaran Dasar Dasar Akuntansi, hal ini dikarenakan proporsi mata pelajaran akuntansi memiliki jam yang paling banyak dari pada mata pelajaran yang lain. Mahasiswa yang memiliki latar belakang Pendidikan SMU jurusan IPS memiliki bekal yang cukup setelah Mahasiswa dari SMK akuntansi untuk mengikuti pembelajaran Dasar - Dasar Akuntansi karena jam pelajaran akuntansi lebih banyak dari pada mata pelajaran yang lain di SMU jurusan IPS. Sedangkan Mahasiswa yang memiliki latar belakang yang lain tentu akan memiliki bekal yang kurang untuk mengikuti pembelajaran Dasar - Dasar akuntansi.

Dari hasil penelitian diperoleh data latar belakang pendidikan mahasiswa Sebagai Berikut :

Tabel. 3

Latar Belakang Pendidikan Mahasiswa

\begin{tabular}{|l|c|c|}
\hline \multicolumn{1}{|c|}{ Jenis Sekolah } & Jumlah & \% \\
\hline SMK Jurusan Akutansi & 2 & 4,44 \\
\hline SMU Jurusan IPS & 36 & 80,00 \\
\hline SMU Jurusan IPA & 7 & 15,55 \\
\hline
\end{tabular}

Dari tabel latar belakang pendidikan mahasiswa dapat terlihat dari 45 Mahasiswa yang mengikuti pembelajaran akuntansi terdapat 2 mahasiswa atau 4,44\% yang berlatar belakang pendidikan SMK jurusan Akuntansi, 39 mahasiswa atau 80,00\% berlatar belakang pendidikan SMU jurusan IPS dan 7 mahasiswa atau 15,55 \% berlatar belakang IPA. Dari hasil tersebut dapat disimpulkan bahwa latar belakang mahasiswa yang mengikuti pemnbelajaran rata - rata telah memiliki bekal yang cukup untuk mengikuti pembelajaran Dasar - Dasar Akuntansi. Selain latar belakang pendidikan dapat pula disampaikan mengenai latar belakang prestasi di Tingkat SLTA mahasiswa, dari angket yang diisi mahasiswa yang memimta data rata - rata nilai akuntansi diperoleh rata - rata nilai mahasiswa di SLTA yang menjadi mahasiswa di Pendidikan Akuntansi adalah 7,75. dari nilai tersebut berarti bekal yang dibawa mahasiswa untuk mengikutui pembelajar adalah cukup memadai, atau dengan kata lain input dalam proses pembelajaran Dasar -Dasar Akuntansi dilihat dari Prestasi Di SLTA adalah Cukup Baik.

\section{Hasil Evaluasi Transaction}

\section{a. Proses Pembelajaran Dasar - Dasar Akuntansi}

Dari hasil penelitian diperoleh skor tertinggi 119 dan skor terendah sebesar 82 . Dari perhitungan Statistik diperoleh skor rata - rata (Mean) sebesar 100,95, standart deviasi (SD) sebesar 8,89, median sebesar 102,00 dan modus sebesar 100,00

Berdasarkan skor rata - rata ideal (Mean) harapan dan standart Deviasi (SD) harapan yang didapat dari perhitungan rumusan kecenderungan , maka dapat ditentukan distribusdi kecenderungan sebagai berikut : 
Tabel. 4

Distribusi Kecenderungan Proses Pembelajaran Dasar - Dasar Akuntansi

\begin{tabular}{|c|c|c|c|}
\hline Interval Kelas & Frekuensi & \% & Kategori \\
\hline $109,25-119,00$ & 7 & 15,55 & Sangat Tinggi/Sangat Baik \\
\hline $100,50-109,50$ & 17 & 37,77 & Tinggi/Baik \\
\hline $91,25-100,50$ & 14 & 31,11 & Sedang/Cukup Baik \\
\hline$<91,25$ & 7 & 15,55 & Rendah/Kurang Baik \\
\hline
\end{tabular}

Dari distribusi kecenderungan proses pembelajaran Dasar - Dasar Akuntansi ternyata dari 45 reponden terdapat 7 responden atau 15,55\% mendapat Skor Sangat tinggi/Sangat Baik dan Rendah/Kurang Baik , 17 responden atau 37,77 \% mendapat skor tinggi/Baik, 14 responden atau 31,11 \% mendapat skor Sedang/Cukup Baik. Berdasarkan data yang diperoleh dapat ditarik kesimpulan bahwa Proses Pembelajaran Dasar - dasar akuntansi pada Program Studi pendidikan Akuntansi adalah Baik

Selain dari data kuesioner, proses pembelajaran dapat terlihat dari data hasil observasi yang dilaklukan oleh peneliti. Dari hasil observasi dapat disampaikan bahwa saat pembelajaran terlihat kualitas suara dosen yang kurang begitu terdengar dari bagian belakang ruang kelas sehingga menggangu penangkapan mahasiswa yang berada di deretan meja belakang. Terkait dengan materi yang diberikan dapat disampaikan dosen menyapaikan materi dengan cukup jelas dan penguasaan bahan ajar yang bagus hal ini dapat terlihat saat dosen menyapaikan materi baru atau topik baru akan didahului oleh penjelasan yang terkait dengan materi yang diberikan. Materi yang diberikan juga sesuai dengan kurikulum yang diberlakukan, ini dapat terlihat dari silabi yang disusun oleh dosen pengampu mata kuliah.

Metode pembelajaran yang digunakan dosen adalah dengan ceramah dan diskusi iinteraktif yang akan menimbulkan kreatifitas anak untuk melontarkan ide-ide baru, hal ini sejalan dengan penerapan kurikulum berbasis kompetensi yang menuntut keaktifan peserta didik dalam proses pembelajaran. Pengelolaan kelas yang dilakukan oleh dosen terlihat masih kurang karena mungkin ruangan yang memanjang sehingga sering mahasiswa yang dibelakang berbincang sendiri saat dosen memberi penjelasan pada salah satu dari teman mereka yang bertanya.

Latihan yang diberikan oleh dosen saat pembelajar Dasar dasar Akuntansi tergolong cukup memadai, hal ini terlihat dengan diakhirinya pembahasan untuk setiap topik dengan pemberian kasus yang relevan dengan topik bahasan yang disampaikan yang didahului dengan contoh - contoh.

Dari observasi pelaksanaan Proses pembelajaran Dasar - Dasar Akuntansi maka dapat disimpulkan proses pembelajaran telah terlaksanan dengan baik

\section{Hasil Evaluiasi Outcomes}

\section{a. Pemahaman Mahasiswa}

Dari perhitungan Statistik diperoleh skor rata - rata (Mean) sebesar 15,31, standart deviasi (SD) sebesar1,48, median sebesar 15,00 dan modus sebesar 15,00. Berdasarkan skor rata - rata ideal (Mean) harapan dan standart Deviasi (SD) harapan yang didapat dari perhitungan rumusan kecenderungan, maka dapat ditentukan distribusdi kecenderungan sebagai berikut :

\section{Tabel.5}

Distribusi Kecenderungan Pemahaman Mahasiswa

\begin{tabular}{|c|c|c|c|}
\hline Interval Kelas & Frekuensi & $\mathbf{\%}$ & Kategori \\
\hline $17,75-20,00$ & 1 & 2,22 & Sangat Tinggi/Sangat Baik \\
\hline $15,50-17,75$ & 18 & 40,00 & Tinggi/Baik \\
\hline $13,25-15,50$ & 23 & 51,11 & Sedang/Cukup Baik \\
\hline$<13,25$ & 3 & 6,66 & Rendah/Kurang \\
\hline
\end{tabular}


Dari distribusi kecenderungan dari 45 reponden atau 2,22\% mendapat Skor Sangat tinggi, 18 responden atau 40,00\% mendapat skor tinggi, 23 responden atau $51,11 \%$ mendapat skor Sedang, 3 responden atau 6,66 mendapat skor rendah.

Berdasarkan data yang diperoleh dapat ditarik kesimpulan bahwa pemahaman mahasiswa setelah Proses Pembelajaran Dasar - dasar akuntansi pada Program Studi pendidikan Akuntansi adalah Sedang.

\section{b. Nilai Akhir Mahasiswa}

Dari perhitungan Statistik dapat terllihat skor rata - rata (Mean) sebesar 82,08, standart deviasi (SD) sebesar 11,40, median sebesar 85,00 dan modus sebesar 95,00 .

Berdasarkan skor rata - rata ideal (Mean) harapan dan standart Deviasi (SD) harapan yang didapat dari perhitungan rumusan kecenderungan , maka dapat ditentukan distribusdi kecenderungan sebagai berikut :

Tabel.6

Distribusi Kecenderungan Nilai Mahasiswa

\begin{tabular}{|c|c|c|c|}
\hline Interval Kelas & Frekuensi & \% & Kategori \\
\hline $86,24-95,00$ & 20 & 44,44 & Sangat Tinggi \\
\hline $77,50-86,24$ & 9 & 20,00 & Tinggi \\
\hline $68,75-77,50$ & 10 & 22,22 & Sedang \\
\hline$<68,78$ & 6 & 13,33 & Rendah \\
\hline
\end{tabular}

Dari kecenderungan nilai mahasiswa, ternyata dari 45 Mahasiswa terdapat 20 atau 44,44 \% mendapat Skor Sangat tinggi, 9 Mahasiswa atau 20,00 \% mendapat skor tinggi, 10 mahasiswa atau 22,22 \% mendapat skor Sedang, 6 mahasiswa atau 13,33\% mendapat skor rendah. Berdasarkan data yang diperoleh dapat ditarik kesimpulan bahwa pemahaman mahasiswa setelah Proses Pembelajaran Dasar - dasar akuntansi pada Program Studi pendidikan Akuntansi dilihat dari nilai Ujian Akhir adalah sangat tinggi

Simpulan

Berdasarkan deskripsi dara dan uraian yang telah disampaikan, penelitian ini telah dapat ditarik kesimpulan sebagai berikut :

1. Latar belakang pendidikan mahasiswa yang mengikuti pembelajaran Dasar Dasar Akuntansi terdiri dari 4,44 \% berasal dari SMK jurusan Akuntansi, 80,00 \% berasal dari SMU jurusan IPS dan 15,55 dari SMU jurusan IPA.

2. Motivasi Mahasiswa yang meniguki pembelajaran Dasar - Dasar Akuntansi termasuk kategori sedang yakni 33,33 \% dari data kuesioner maupun observasi

3. Dari hasil Domumentasi dan Observasi diperoleh data yang terkait ketersediaan sarana dan prasarana untuk pembelajaran Dasar - Dasar akuntansi yang termasuk memadai untuk pembelajaran, ini terlihat adannya berbagai media yang tersedia, Laboratorium manual dan Komputer serta sarana lain yang memadai.

4. Penggunaan sarana dan prasarana dalam pembelajaran Dasar - Dasar Akuntansi menjukkan kategori sedang/cukup baik yakni $44,44 \%$, begitu pula jika dilihat dari hasil observasi menunjukkan penggunaan sarana dan prasaranan yang belum optimal untuk pembelajaran.

5. Proses pembelajaran Dasar - Dasar akuntansi yang dilaksanakan menunjukkan kategori yang baik yakni $37,77 \%$, walaupun dari data observasi masih menjukkan kurang optimal untuk pengedalian kelas namum secara umum proses pembelajaran berjalan dengan baik.

6. Pemahaman mahasiswa setelah mengikuti pembelajaran Dasar - Dasar Akuntansi menunjukan kategori baik yakni 40,00\%, 
7. Hasil nilai mahasiswa setelah menikuti pembelajaran Dasar - Dasar Akuntansi yang terdiri dari Ujian Tengah Semester, Ujian Akhir Semester serta tugas - tugas yang diberikan termasuk kategori sangat baik yakni 44,44\%

\section{Daftar Pustaka}

A Ubaidillah. (2002) Pendidikan demokrasi dan kualitas negara.diambil 14 Juli 2003,dari : http://www.smu-net.com/main.php?mode=17act=pb\&xkd=14).

Fess, Philip E. \& Niswonger, C. Rollin. (1970) Accounting Principles.

Kaufman, R. \& Thomas S (1980). Evalution without Fear. New York Viewpoints.

Larson, Kemit D. \& Pyle William (1998) Fundamental Accounting Priciples. Eleventh Edition. Irwin Homewood Illionis

Mulyoto(2002).Pembelajaran yang demokratis. Diambil 14 Juli 2005, dari(http://www.smu-net.com/main.php?mode=17act=pb\&xkd=21

Nasution,S.(1982) Azas-azas kurikulum.bandung CV.Yemmars.

Paton, W.A. \& Littleton, A.C (1970) An introduction to corporate Accounting Standart.American Accounting Association

Rudarti(2002). Metode pengajaran alternatif agar menarik, diambil 14 Juli 2005, dari: http://www.smu-net.com/main.php?mode $=17 \mathrm{act}=\mathrm{pb} \& \mathrm{xkd}=20$ )

Worthen, Blaine. R. \& Sanders, James. R. (1993). Educational Evaluation: a system theory and practice. California: Charles A Jones Publishing Company.

Warren. Reeve \& Fess (2005) Accounting. Thomson south western

weygant.Kieso.kimmel (2005). Accounting Priciples.Thomson south wester 


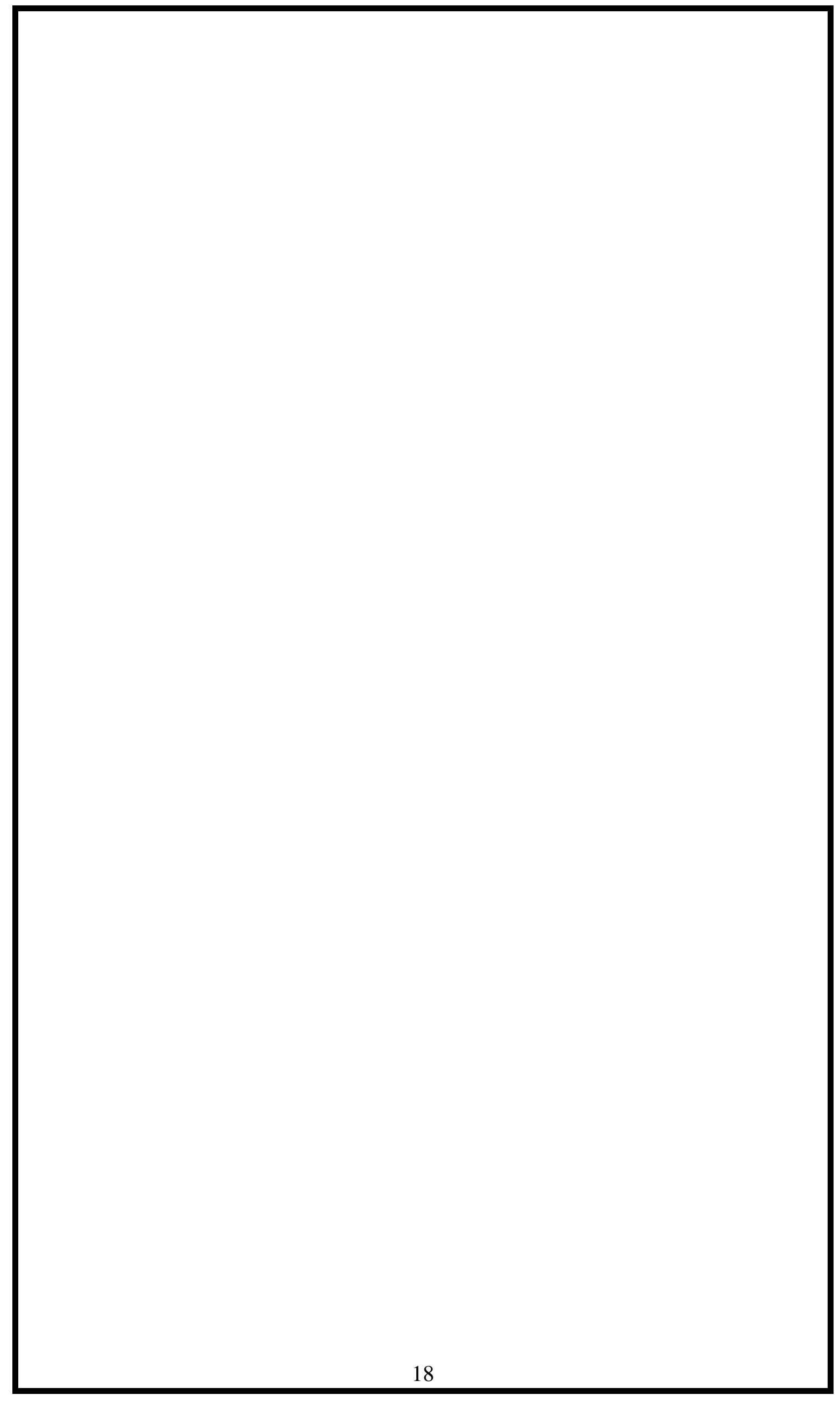

